\title{
Itsas estazio biologikoen historia eta kostaldeko bioaniztasunaren ikerketa
}

\author{
(The history of the marine biological stations and the research \\ of coastal biodiversity)
}

Ibon Cancio*

CBET Research Group, Dept. Zoology \& Animal Cell Biology; Faculty of Science \& Technology and Research Centre for Experimental Marine Biology and Biotechnology

(PiE-UPV/EHU)

\begin{abstract}
LABURPENA: Itsasoa ez da guretzat, gizakiontzat, ohiko bizi-eremua. Ez da gure habitata eta gure historiaren zati nagusian lur-eremuak banatzen zituen pasabidea edo amildegia baino ez da izan. Horretan, bertan bizi diren organismoak eta haien berezitasunak arrotzak izan zaizkigu mendeetan zehar. Itsasoarekiko hurbilketan dugun zailtasun horretan gizakiok trebezia eta azpiegitura bereziak garatzeko beharrean aurkitu gara. Itsasontziak eta laginketa-metodo aproposak behar ditugu, baina baita itsasotik hurbil egonkorki kokatuak dauden ikerketa-azpiegiturak eta «egoitzak» ere. Izan ere, eta oro har, kostaldeetan aurkitzen da itsaso guztietan bioaniztasun ugariena, lurraren eta itsasoaren arteko mugak biziaren loratzea ahalbidetzen baitu. Aniztasun horren ikerketa izan da itsas estazio biologikoen xedea XIX. mendetik. Haien ikerketa-bidaian zientifikoei egoitza eskaintzeko sortutako ikerketa-azpiegiturak, tresneria, babesa, eta trebatutako laguntza zein oinarrizko ezagutza eskaintzen dituzten «itsas geltokiak». 150 urte luzeetako bidaia honetan, itsasoko organismoek lehen lerroko oinarrizko ikerketarako bideak eman dituzte (itsas eredu biologikoen erabileraz). Gainera, itsasoko izakiok gizakiontzat ezinbesteko baliabideak ustiatzeko aukerak eman dituzte (arrantzua, itsas akuikultura...), «bioteknologia urdina»ren garapenarekin itsas eskualdeen garapen sozioekonomikorako etorkizunezko promesa bilakatu diren bitartean.
\end{abstract}

HITZ GAKOAK: itsas estazio biologikoak, bioaniztasuna, eboluzioa, Biologiaren historia, itsas baliabide biologikoak, itsas erdu biologikoak.

\begin{abstract}
The sea is not the normal living place for us, humans. It is not our habitat and during a big part of our history it has been the pass way, or the void, in between lands. In that way, the organisms that inhabit the oceans and their characteristics have been mostly unknown during centuries. In our difficulty to approach the sea, we have faced the need of developing special skills and infrastructures. We need vessels and specific sampling methods, but also research infrastructures and shelter places permanently placed near the seashores. In general, most of the biodiversity in all the oceans can be found in the coastal areas, since the interface between land and sea allows the blossoming of life. The study of this biodiversity is in fact the mission of marine biological stations since their conception in the XIXth century. These are institutions created to shelter travelling scientists; «rest stop sites» that offer research infrastructure, equipment, protection, trained help and background knowledge to visitors. In this 150 years long journey marine organisms have provided avenues for basic science at the forefront of research through the utilization of marine model organisms. In the same way, marine life has provided opportunities to exploit resources useful for the humankind (fisheries, marine aquaculture...), while the development of «Blue Biotechnology» holds the promise to contribute to the socioeconomic development of maritime regions.
\end{abstract}

KEYWORDS: marine biological stations, biodiversity, evolution, history of Biology, marine biological resources, marine model organisms.

* Harremanetan jartzeko / Corresponding author: Ibon Cancio, CBET Research Group, Dept. Zoology \& Animal Cell Biology: Faculty of Science \& Technology and Research Centre for Experimental Marine Biology and Biotechnology (PiE-UPV/EHU), Euskal Herriko Unibertsitatea. Areatza Hiribidea s/n, 48620 Plentzia, Euskal Herria. - ibon.cancio@ehu.eus - https://orcid. org/0000-0003-4841-0079

Nola aipatu / How to cite: Cancio, Ibon (2020). «ltsas estazio biologikoen historia eta kostaldeko bioaniztasunaren ikerketa»; Ekaia, ale berezia 2020, 29-55. (https://doi.org/10.1387/ekaia.21074).

Jasoa: 26 abuztua, 2019; Onartua: 29 urria, 2019

ISSN 0214-9001 - elSSN 2444-3255 / (c) 2020 UPV/EHU

Obra hau Creative Commons Atribución 4.0 Internacional-en

lizentziapean dago 

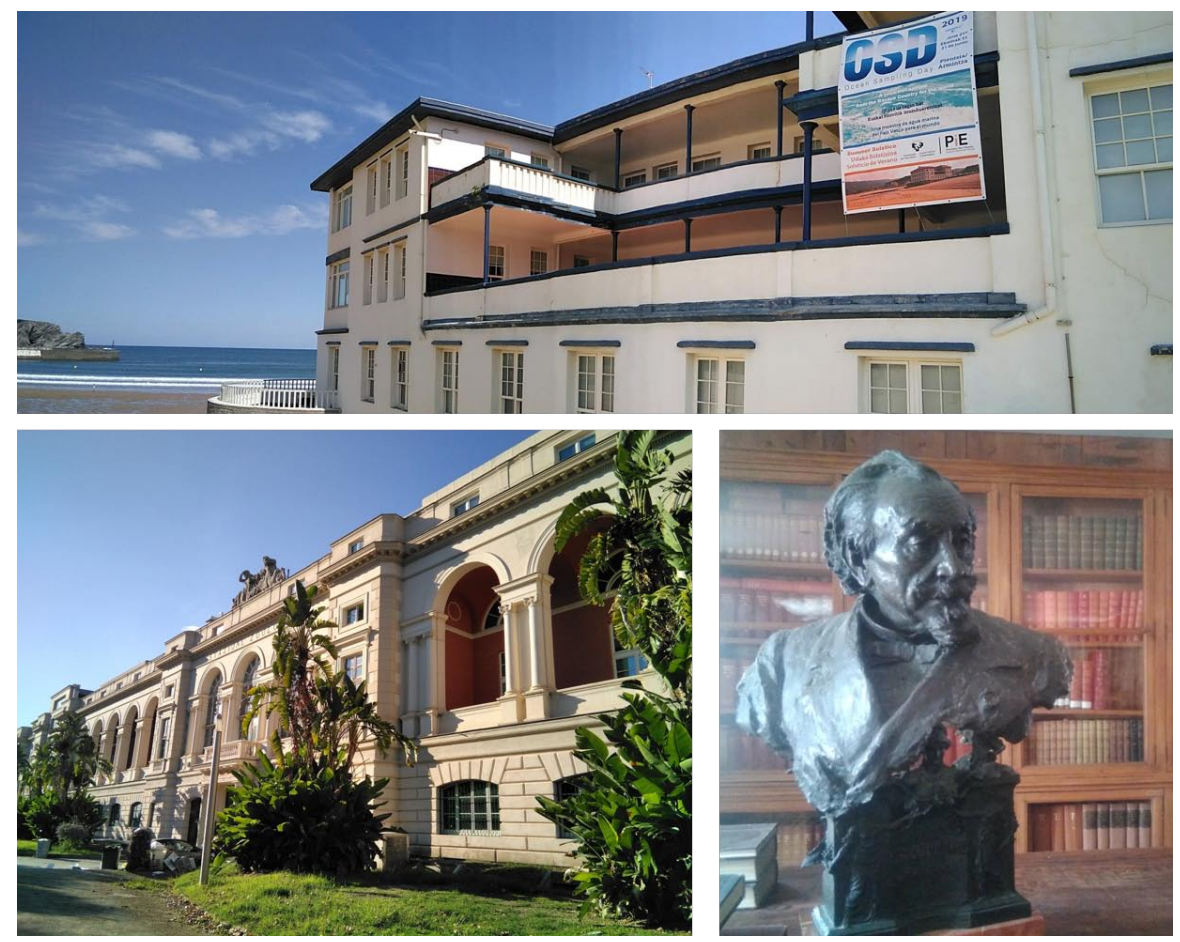

1. irudia. XXI. mendean zabalduriko itsas estazioa, Plentziako Itsas Estazioa, eta 1872an zabaldutako beste bat, Napoleseko Anton Dohrn Estazio Zoologikoa. Plentziako itsas estazioko argazkiak bi gauza islatzen ditu: itsasoarekiko hurbiltasuna eta Ozeanoen Laginketa Eguna (OSD). Egitasmo horrek munduko itsas estazioak itsasoko ur-lagin bat hartzen jartzen ditu egun berean, udako solstizioan, eta ur-lagin horietan agertzen den mikrobioen bioaniztasuna sekuentziatu egiten da, sekuentziazio metodo masibo paraleloen bitartez. Agertzen den bustoa Henri de Lacaze-Duthiers-ena da, Sorbonako Unibertsitateari atxikiak dauden Roscoffeko (1872) eta Banyuls sur Mer-eko (1882) itsas estazioen sortzailea, Roscoffeko liburutegi zoragarrian.

\section{ITSAS ESTAZIO BIOLOGIKOAK EUROPAKO GEOGRAFIAN}

Euskal Herriko Unibertsitateko Plentziako Itsas Estazioa (PiE-UPV/ EHU) 2012ko uztailaren 17an zabaldu zituen bere ateak (1. irudia). Zientzia eta Teknologia Fakultateko irakasle eta ikertzaile-talde baten eraginpean ireki zituen ateak, Bizkaiko Foru Aldundiaren, Kutxabanken eta Unibertsitatearen laguntzaren bitartez. Laguntza horrek Plentziako hondartzaren gainean kokaturik zegoen antzinako ospitale bat berreraikitzen lagundu zuen. Horrela, ikerketa zentro modernoa eraiki zen, itsasoaren inguruko ikerketa biologiko, kimiko zein bioteknologikoa burutzen zuen 
unibertsitateko irakasleriak bere egoitza izan zezan. Plentziako Itsas Estazioak baditu helburu estrategiko batzuk, zeinak lerrokatzen baitira bere ikerketa-taldeek itsasoaren osasunaren azterketaren inguruan egindako ikerketekin, itsas baliabide biologikoen eta itsasoaren osasunaren arloko Unibertsitateko graduondoko irakaskuntzaren inguruko beharrizanekin eta gizarteari zabaltze-egitasmoaren inguruan Unibertsitateak «eman ta zabal zazu» bere goiburuari jaramon egin beharreko funtzio akademikoarekin.

Baina PiE-UPV/EHU instituzio gaztea da, Europako lehen itsas estazioa 1843an zabaldu baitzen, Ostenden (Belgika). Gaur arte etengabe zabalik egon diren bi estazio zaharrenak, aldiz, Frantzian zabaldu ziren, Concarnau-n (1859) eta Arcachon-en (1863) [1,2]. 1910. urterako baziren dozenaka itsas estazio sortuak, Europan barreiaturik, Espainiatik Errusiako Artikoraino eta Groenlandiatik Adriatiko edota Itsas Beltzeraino. Bakarrik frantziar estatuan, XX. mendearen hasieran honelako 14 instituzio zeuden, gehi beste bat garai hartan frantziarra zen Algerian. Horietako batek, Arcachonekoak, eranskin bat zabaldu zuen 1887an Ipar Euskal Herrian, Getarian, Arcachoni kostalde arrokatsuetarako sarbidea emateko asmoz, eta zenbait hamarkadatan zabalik egon zena. Honen guztiaren deskribapen zehatza egin zuen Charles A. Kofoidek 1910ean [3] argitaratutako txostenean (2. irudia). Urtebeteko bidaia egin zuen Europan barrena, Estatu Batuetako Barne Saileko Hezkuntza Bulegoaren agindupean. Haren xedea, Europako itsas estazioen antolaketa eta egiteko moduak aztertzea zen, ikasitakoa Estatu Batuetan planifikatuta zeuden erakundeetan (Scripps Institutu Ozeanografikoan, bereziki) aplikatu ahal izateko. Europa zen itsasoaren ikerketa biologikoaren hastapenetan begiratu beharreko ispilua.

Instituzio horiek hein handi batean unibertsitateen mende zeuden, baina ez guztiak: gutxi batzuk pribatuki zientzialari bakanen burutazio eta lanen bidez sortu ziren; beste batzuk, berriz, zientziaren sustapenerako erakundeen magalean sortu ziren, Arcachonekoa (Société Scientifique d'Arcachon) edo Plymoutheko Itsas Laborategia (British Marine Association), kasurako [3]. Batzuk lehendik baziren eraikinetan ezarri ziren; ospitaleetan, gazteluetan, txalupak gordetzeko eraikinetan, monasterioetan; beste batzuk apropos eraikitako eraikinetan; eta beste batzuk mugikortasuna ahalbidetzen zuten barkuetan edota egurrezko txabola desmuntagarrietan ezarri ziren. Batzuk urte-sasoiari eta bioaniztasunaren loratze-momentuei oso loturik zeuden, eta udan bakarrik zabaltzen zituzten ateak, unibertsitateko ikertzaileen oporraldietako lana bideragarri egiteko $[3,4]$. Beste batzuk urte osoan zeuden zabalik, nahiz eta langile iraunkorren plantilla murritza izan gehienetan. Zerk eragin zuen, baina, kostaldeko biologiaren ikerketari (eta irakaskuntzari) loturiko instituzioen loraldi hura Europan? Eta, nola da posible XIX. mendean sortutako instituzio horiek gaurdaino bizirik iraun izana, periferikotasunak sortarazitako «erabilpen unitatearen kostea»-aren biderketari aurre eginez? 


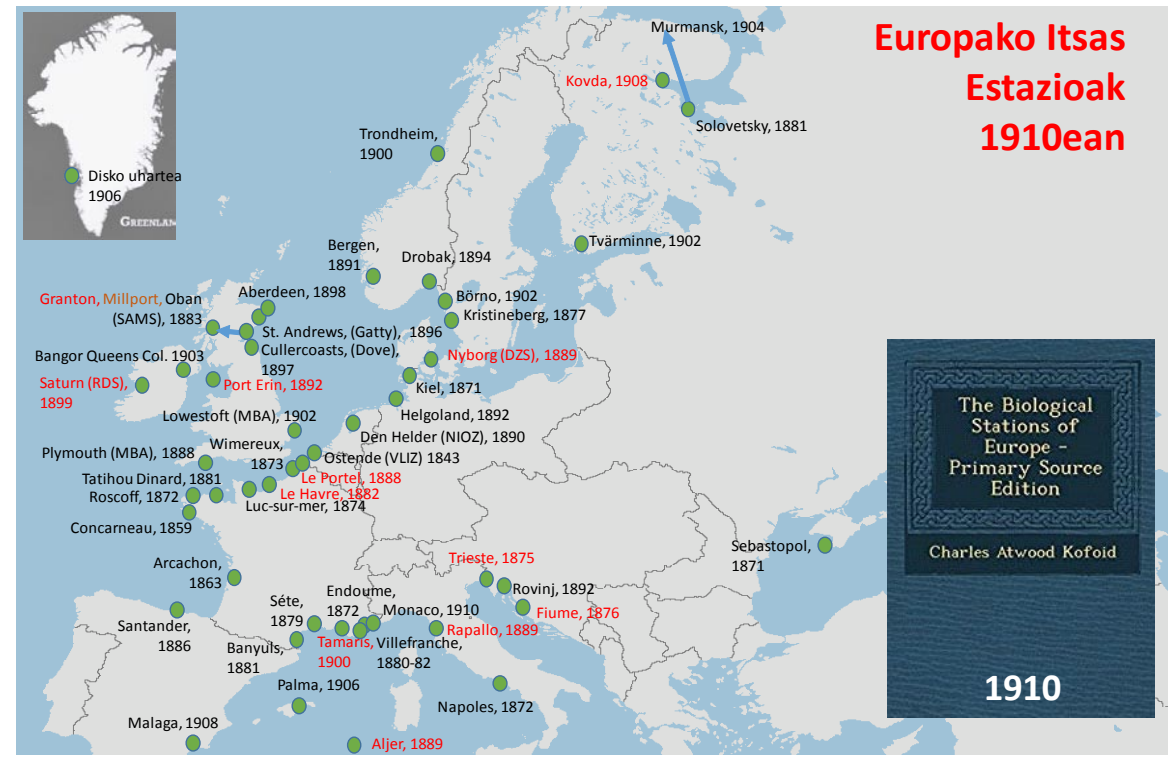

2. irudia. 1910. urtean Charles A. Kofoidek liburu bat argitaratu zuen Europako itsas estazioetan ikusi eta ikasitakoa baliatuz. Garai hartako Europako mapa politikoan, 1910erako lanean zabalik zeuden itsas estazioak azaltzen dira, gehienak liburuan aurkezten direnak. Haien irekiera-urtea azaltzen da, eta zer hiritan kokatuta zeuden (Saturn ontzi bat izan zen leku desberdinetan kokatua izan zena Irlandako kostaldean). Gorriz ageri direnak, arrazoi desberdinak direla medio, itxi egin zituzten eta bertan behera geratu ziren: Bigarren Mundu Gerran bonbaz desegin izanaren ondorioz (Le Portel, Lille Unibertsitatea), zuzendariaren heriotza (Le Havreko Itsas Fisiologiako laborategia) edo gainkostu ekonomikoa (Port Erin, Liverpool Unibertsitatea). Gutxi batzuk lekuz aldatu dira beren historian zehar.

\section{HISTORIA NATURALA: ORDENA JARTZEN NATURAREN BILTEGIAN}

XIX. mendea esplorazio naturalistarena izan zen. Noski, itsasoan zeharreko bidaiak eta esplorazioak ugariak izan ziren historian, haien artean Elkanoren eta Urdanetaren lehen eta bigarren mundu-birak. Baina haien guztien xedea zen «Inperio»aren izenean egindako esplorazioa eta beste lurralde batzuetarako garraio-bideak ezartzea, haien ustiaketa egiteko. Hala ere, XIX. mendeak zerbait berria ekarri zuen: bai flota komertzialean, bai herrialde desberdinetako flota esploratzaile armatuetan, naturalistak ere izan ziren bidaiari [1, 4, 5]. Batzuetan, ontzietako medikua zen lan horien arduraduna. Beste batzuetan, zientzialari naturalista bat ontziratzen zen. Ulertuta betiere Historia Naturala medikuntzako ikasketen parte garrantzitsua zela, XIX. mendean ez baitzegoen Biologiako, Geologiako edo 
Zientzietako goi-mailako ikasketarik. Honen adibiderik argienak «HMSBeagle»-en (1831-1836) bidaiatu zuen Charles Darwin (1809-1882) edota «HMS-Rattlesnake»-an (1846-1850) bidaiatu zuen Thomas Henry Huxley (1825-1895) liratekeen.

Guztien artean, historian Ozeanografiaren, baina baita itsasoaren ikerketa biologikoaren, jaiotze-data jartzen duen bidaia «HMS-Challenger» espedizio britaniarrarena (1872-1876) izan zen. Haren funtzioa munduko itsas hondoen esplorazio fisiko-kimikoa izan zen, buruan zutela Europa eta Amerikaren artean telegrafiarako kableak jartzeko informazioa lortzea. Bide batez, haien beste misioa itsaso zabalaren sakoneran bioaniztasunaren esplorazioa izan zen. Bidaia hartan, Marianas-etako hondoak aurkitu zituzten, eta izaki bizidunen banaketa bertikala 8.000 metrotaraino behintzat ailegatzen zela ezarri zuten, aldez aurretik itsas hondoak bizigabeak zirela uste zenean. Challengerrek munduko itsasoetako 4.717 landare- zein animalia-espezie berri bildu zituen $[1,4]$, eta lagin horiek guztiak munduan zehar banatu ziren, herrialde desberdinetako espezialistek (Taxon autoritateak) azter zitzaten. Adibidez, talde honetan, Jenako Ernest Haeckel-ek erradiolarioak eta marmokak aztertu zituen, eta gauza bera egin zuten Alexander E. Agassiz-ek ekinoideoekin Harvarden, Albert Von Kolliker-ek Penatulacea taldeko animaliekin Wurzburg-en, edo Georg Ossian Sars-ek Schizopoda eta Curnacea taldeekin Oslon. Horrelako nazioarteko ikerketaegitasmorik ez zen aurretik ezaguna, eta markatu zuen gaur egun ikerketa zientifikoaren oinarrietan ezarrita dagoen nahitaezko praktika eta lan-moldea, nazioarteko kolaborazioa munduko arazoen konponketa aurkitzeko bidean. Nondik, eta itsasoko ikerketa biologikotik hasita. Challenger espedizioaren ondorio zientifikoak askotarikoak eta oso oparoak izan ziren, eta urteetan argitaratu zituzten bilduma desberdinetan [1, 4]. Horren guztiaren kudeaketarako, «The Challenger Society» antolatu zen. Handik sortu zen Eskoziako lehen itsas estazioa ezartzeko beharra, Eskoziako Itsas Elkartearen eskutik. Horrela, 1883an Granton-eko portuan, Edinburgotik hurbil, lurreratua utzi zen «The Ark» laborategi-ontzia. Geroago, Milport-era mugitu zuten, eta gaur egun Oban-en errotuta dagoen SAMS (Scottish Association for Marine Science) erakundearen aitzindaria da.

Bidaiek itsasoko espezie berriekin hornitu zituzten Europako museo eta unibertsitateak. Gauza bera gertatu zen naturalistek Europako kostaldeetara egindako bidaiekin. Izaki desberdinen bilketatik konparaketarako beharra sortzen da, eta konparaketatik izakiak antzekotasunen arabera harremanak eta ordena ezartzeko grina. Lineok eman zuen, Taxonomiaren hasierarekin, espezieen artean ahaidetasunak ezartzeko aukera. Hala ere, hark guztira sailkaturiko 4.000 animalia eta 7.000 landare-espezieetatik oso gutxi ziren itsastarrak. Sailkatzeko grina hura Historia Naturaleko museoen sorrerarekin hazi zen. Munduko Historia Naturaleko museo handienen artean kokatu behar dugu Parisekoa, eta haren «Les Jardins des plants»-ean badago erai- 
kin berezi bat Anatomia Konparatuko eta Paleontogiako aitari, George $\mathrm{Cu}-$ vier-i (1769-1832), eskainia. Cuvier-ek Normandian hartu zuen ostatu Parisetik erdi ihesi irtenda, 1793-1794 bitartean, Frantziar Iraultzan Parisen gailendu zen «Izu Garaia»-n, eta orduan ikusi zuen estrainekoz itsasoa. Hortik sortu zitzaion itsas animalien azterketarako grina eta gerora moluskuen, arrainen eta batik bat zetazeoen ikerketa hartu zituen ardatz (3. irudia). Berak zabaldu zuen Lineok hasitako sailkapen taxonomikoa, klaseak filumetan taldekatuz, eta sailkapenean bai fosilak eta bai espezie bizidunak barneratuz [1]. Haren oinordekoak ere itsas animalien ikerketan nabarmendu ziren, eta Concarneau-ko Itsas Zoologia eta Fisiologiako Laborategia Pariseko Historia Naturaleko Museoarekiko lotura handiarekin zabaldu zen, hura itsasoko laginekin hornitzea izan baita beti haren xedeetako bat. Gogoratu Jules Vernek 1869-70. urteen bitartean argitaratu zueneko «20.000 legoako bidaia itsaspetik» eleberriko protagonista «Pariseko Historia Naturaleko Museo»-ko naturalista zela, Pierre Aronnax. Eleberria irakurri duenarentzat, itsasoetako bioaniztasunaren zerrenda taxonomiko bat da.

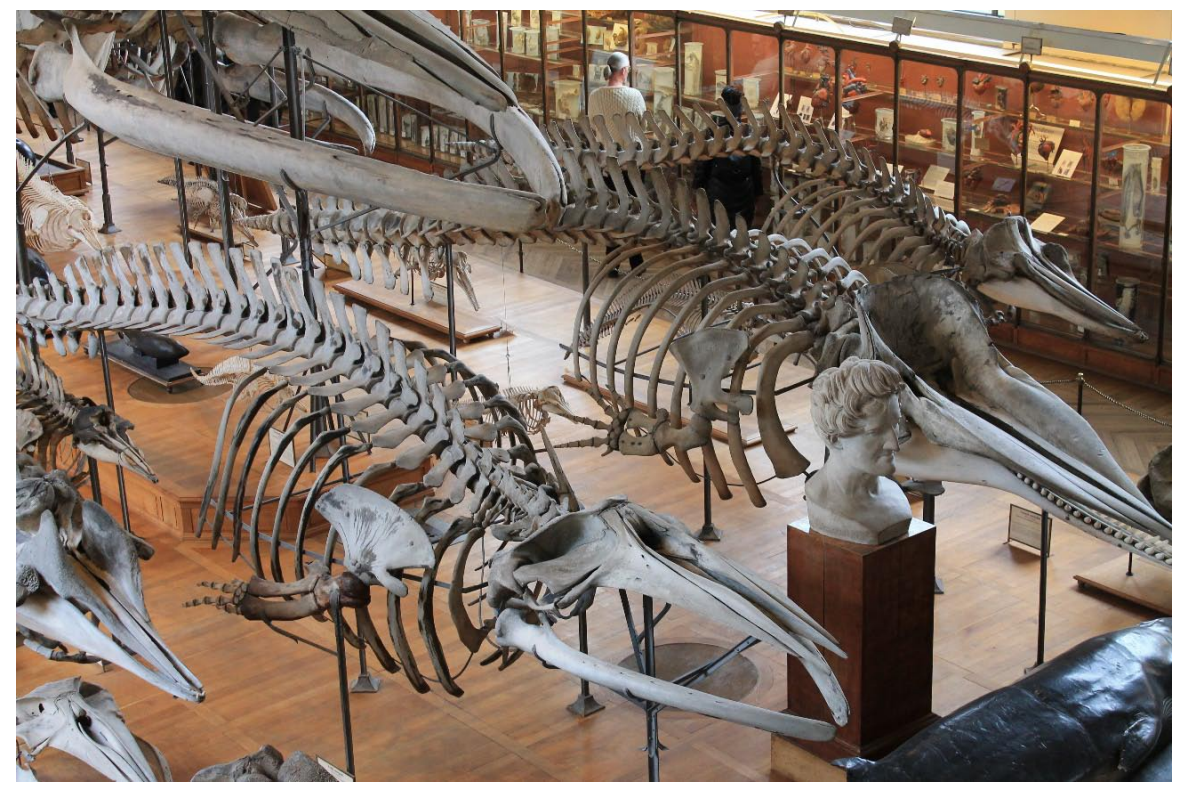

3. irudia. Cuvierren bustoa Pariseko «Jardins des plants»-eko anatomia konparatuko eraikinean. Haren inguruan, zetazeoen eskeletoak, haien artean Cuvier moko-balea. Anatomia, Fisiologia eta Enbriologia Konparatuak kontsidera daitezke XIX. mendean kostaldeko bioaniztasunari erreparatzeko arrazoiak.

Johannes Müller-ek (1801-1858), Berlineko Unibertsitateko Historia Naturaleko Museoaren buruak, eta XIX. mendeak eman zituen Pru- 
siako eta historiako zientzialari handienetakoen irakasleak (hala nola; Schwan, Schleiden, Henle, von Helmholtz, R. Virchow, E. du Bois-Reymond, Remak, Von Kolliker, Ludwig, Haeckle edo Wund: a zer nolako eminentzien taldea!!), mikroskopia konparatua eta ikerketa fisiologikoak zituen ardatz, baina gehienetan itsasoko animalien azterketa zuen abiapuntu [1]. Udan, Helgoland-eko uhartera edota Italiako kostaldera egiten zituen txangoetan, laginak hartzen zituen bere ikasleekin. Lagin horietariko askok bere museoaren ondarea osatuko zuten, baina, era berean, haien azterketaren bidez Fisiologia Konparatuko zutabeak ezarriko zituen. Azterketa mikroskopikoa defendatuko zuen hurbilketa metodologiko ezinbestekotzat. Gerora, haren ikasleek gauza bera egingo zuten hurbilketa kimiko eta biokimikoekin, diziplina horien hastapenetan, ikerketa-esparrua Enbriologia Konparatura eta Zitologiara hedatuz. Hain zuzen ere, Enbriologia Konparatuak emango zituen baliabide berriak zenbait ornogabe sailkaezin sailkatu ahal izateko [6].

Kostaldera egindako udako txango haiek turismo zientifikotzat har ditzakegu, gerora 1850 urteaz geroztik beste hainbatek egingo zuten bezala. Adibidez, Ernst Haeckel-ek berak eta Nikolai Miklouho-Maclay-ek Lanzarotera egindako espedizioa, edota Anton Dohrn-ek, N. MiklouhoMaclay-ek edo Élie Metchnikoff-ek Messinara eta Napolesera egindakoak [7]. Kasu guztietan arazo berak sortzen ziren: laginketarako materiala norberarekin garraiatu beharra, lagintzen zen tokietako habitaten eraketaren eta bertoko biotaren bizi-zikloen gaineko ezagutzarik eza, eta jasotako material biologikoa aztertzeko tresneriaren eta baliabideen falta.

Publiko orokorrarentzako turismoa eta asteburuko aisialdiko kostalderako bidaien hasiera ere XIX. mendean koka ditzakegu. Britania Handian trenbide-sarearen zabalkundeak lagundu zuen horretan, denbora gutxian kostaldea eskuragarri egin zen, eta gizarte viktoriarrean ohikoa bilakatu zen itsasaldien arteko guneetako oskolen eta izakien bilketa, eta bilduma amateurren sorrera. Badira esaten dutenak XIX. mendearen erdialdean muskuiluak, aktiniak eta karrakelak etxeko «maskotak» bihurtu zirela. Orduan zabaldu ziren akuariofiliako lehenengo dendak Londresen, eta baita lehenengo akuario publikoak ere. Londresen zabaldu zen lehena (1853), eta ondoren, beste batzuen artean, Paris, Viena, Berlin edota Washingtonekoak etorriko ziren.

Historia Naturala aztertzeko grina horretan beharrizan deskriptibo bat nabaria da, eta lan hori burutzeko naturara bidaiatzea baino hobea naturan bertan txertatuta bizitzea da. Louis Agassiz (1807-1873) Amerikako Zoologiaren aita kontsideratua denak esaten zuenez, «ikasi Natura eta ez liburuak» [8]. Horrek bultzada handia eman zion itsas estazioen sorrerari. Berak ireki zuen lehenengo udako itsas estazioa Estatu Batuetako Ekialdeko kostaldean (Penikese laborategia, 1873), Woods Hole-eko Itsas Laborategia-ren aitzindaria izango zena [8]. Udako ikastaroak ematen ziren His- 
toria Naturaleko irakasleen prestaketarako, eskoletan naturarekiko hurbilketa sustatzearren. Eskola haietatik Ameriketako Itsas Biologiaren figura handienetarikoak igaro ziren. Hango eskoletan emakumeek izan zuten parte-hartze garrantzitsua, eta Woods Hole-eko itsas laborategiaren (1888) irekieran, garrantzitsua izan zen Bostoneko Emakumeen Heziketarako Elkartearen diru-laguntza. Instituzio horretan 50 Nobel saridun baino gehiago aritu izan dira, egonkorki edo bisitari moduan, ikerketan edo irakaskuntzan. Europan, era berean, T.A. Huxley-ek gaur egun ezagutzen dugun zientzien irakaskuntza akademikorako oinarriak ezarriko zituen, laborategian bideratutako lan esperimentala jarriz oinarrian [9]. Funtsean zientziak diziplina filosofiko teoriko eta deskriptibo hutsak izatetik diziplina induktibo esperimentalak izatera pasatuko ziren, eta Biologian jakintza-esparru desberdinak hasiko ziren adarkatzen: Zoologia, Botanika, Fisiologia, Enbriologia, Zitologia, Biokimika... Ondorioa nabaria da, itsasoa ikerketa-zentroan egonik, laborategiak kostaldera eraman beharra zegoen [9], eta Huxley laborategi horietako baten lehendakari bilakatuko zen 1888. urtean. Historia Naturalaren ikuspuntutik, beraz, hauexek izan ziren itsas estazioak ezartzeko arrazoi nagusiak:

1. Bioaniztasun handiko kostaldeko habitaten azterketa. Itsas estazioek erraztuko lukete etengabe, eta urte osoan zehar, organismo desberdinen bizi-zikloak aztertzen naturan bertan [1, 4, 5, 10]. Bestetik, ekosistemen deskribapena eta bioaniztasunaren in situ azterketa bermatzen zuten, hau da organismo desberdinen arteko harremanen azterketa. Horrela, itsas estazioetatik bertatik aldizkari zientifikoak sortu ziren: «Fauna und Flora des Golfes von Neapel und der angrenzenden Meeresabschnitte» edo «Bulletin de la Station Biologique d'Arcachon». Horrek bultzarazi zuen itsas estazioen irekiera kostaldeko ekosistema berezien azterketarako; batzuk aipatzearren, Bretainiako gune megamareala Roscoffen (1872), Baltikoa Tvärminnen (1902), Itsaso Beltza Sebastopolen (1871), Itsaso Zuria Solovetsky-n (1881) eta Artikoa Alexandrovsk-en (1904) [3].

2. Funtzio museistikoa eta ikerketarako itsas organismoen hornidura. Itsas estazioen funtzio nagusienetarikoa zen organismoak biltzea eta Europako museo eta unibertsitateentzat eskuragarri uztea. Adibidez, Triesteko itsas estazioa, non medikuntzako ikasle gazte batek, Sigmund Freud-ek (1856-1939), bere lehenengo ikerketak egin baitzituen (aingiren gonaden aurkikuntzan saiatu zen 1877 an egindako hilabeteetako egotaldian), Vienako museoa itsas organismoekin hornitzeko jaio zen. Napoleseko Anton Dohrn Estazio Zoologikoan (1. irudia), hornitzaile funtzio hau sakonago garatu zuten eta organismoak zein organismoen laginak (mikroskopiarako gertakinak, adibidez) prestatzeko metodologia espezifikoak garatu zituzten, eta laginak hornitzeko salmenta-presioen katalogoa prest 
zeukaten, jadanik XIX. mendean. Beste adibide bat Santiago Ramon y Cajal-ek (1852-1934) ematen digu. Egotaldiak egin zituen Mallorcako (Porto Pi) eta Banyuls sur Mer-eko Itsas Estazioetan, eta Santanderrekoa ere bisitatu zuen. Zefalopodo-espezieen erretina eta zentro optikoen gaineko artikulua argitaratu zuen 1917. urtean. Madrilen egindako ikerketa mikroskopikoak Santanderreko eta Mallorcako Itsas Estazioetatik (gaur egun Espainiar Institutu Ozeanografikoaren, IEO-ren, egoitzak direnak) eskuratutako laginetan oinarritu ziren [11].

3. Historia Naturala eta bioaniztasuna aztertzeko eta azaltzeko profesionalen prestaketa. Hau izan zen Estatu Batuetako lehen itsas estazioen sorrerako arrazoi nagusietarikoa, eskoletarako irakasleak prestatzea [8]. Europan itsas estazio gehienek Unibertsitateekiko lotura handiarekin sortu ziren, eta, haien xedea ikerketa bazen ere [3], bultzada handia eman zioten landa-lanean egindako doktoretza aurreko ikasketei [9]. Horrela, itsas estazioak nahitaezkoak izan dira hamarkadetan Biologiako diziplinen adarkatze-prozesuetan, Fisiologiaren eta Enbriologiaren sorreratik, gaur egungo Genomika Konparaturaino. Beste funtzio bat etengabeko heziketarena izan da, kurtso espezializatuen eskaintzaren bidez (taxonomia, laginketa eta bestelako laborategiko teknikak...), edota alor desberdinetako profesionalentzako ohartze/trebatze-ikastaroen bidez (arrantzaleak, akuikulturako profesionalak...) [1, 3, 8]. Heziketarena beti izan da itsas estazioen biziraupenean sostengua eman duen jarduera bat, eta gaur egun ere balio handia du zientzia gizarteratzeko.

4. Historia Naturala biztanleriari erakusteko beharra. Horretan adierazgarria da Europan itsas estazio askok akuario publiko izateko egindako apustua. Horixe da zaharrenetakoa eta ospetsuena den Napoleseko Anton Dohrn Estazio Zoologikoaren kasua (1872). Egia esan, estazioa Napolesen kokatzeko arrazoietako bat, hiriaren beraren tamaina eta urtean zehar erakartzen zuen publiko andana izan zen. Jende horrentzat guztiarentzat Aquariuma beste ikuskizun erakargarri bat bilakatuko zen. Eta zer esan Monakoko akuarioaz (1910), inork gutxik daki ikerketarako itsas estazio biologiko gisa jaio zela, Monakoko printzea itsas naturalista sutsua baitzen. Beste horrenbeste gertatu zen Plymouthen (1888), Helgolanden (1892)... Akuario hauek hurbildu zuten lehenbizikoz Itsas Biologiaren xarma biztanleriarengana, bide batez dirua ekarriz estazioen mantenurako. «The Ark» laborategi-ontzi txikia bisitatzeko, Milport-eko Port Loy-n ainguratuta egon zen bitartean, penike bat kobratzen zitzaion bisitari bakoitzari: horrek instalazioaren mantenuan laguntzen zuen. Baina 1900. urtean ekaitz batek ontzia hondoratu egin zuen. 


\section{EBOLUZIOAREN TEORIA, IRAULTZA BAT BIZIAREN ULERMENERAKO ETA ITSAS ESTAZIOETAN OSTATU HARTU ZUENA}

Darwin-eta eboluzioaren teoria guztia aldatzera etorri ziren 1859. urtean, ez soilik Biologian, baita gure bizia eta izaera ulertzeko moduan ere. Harrezkeroztik badakigu ez dagoela ezer Biologian azaldu daitekeenik eboluziotik kanpo. Oihartzun gutxi izan badu ere, zirripedioak garrantzitsuak izan ziren teoriaren mamitze- eta biribiltze-lanean. Darwinek buruan nahiko bideratua zeukan bere teoria Beageletik Britainia Handian lurreratzean, 1836. urtean, eta 1844an bazeukan liburuaren zirriborro bat. Zer egin zuen 1859. urtean liburua argitaratu arte? Bere buruarentzat izena egin behar zuen Britania Handiko gizarte zientifikoan, eta erakutsi zientzialari fidagarria zela. Galoiak irabazi behar zituen. Horretarako, lau liburutan argitaratuko zen zirripedioen inguruko monografia bat idaztera bideratu zituen bere egunak. Liburuak 1846. eta 1854. urteen artean argitaratuko ziren [12].

Zirripedioak (lanpernak eta balanoak) denbora luzez moluskuen taldearen baitan sailkatu zituzten. Darwin lanean hasi zen garairako, jadanik krustazeoen artean sailkatuta zeuden, beste batzuen artean Cuvierren lanari esker, baina oso ezezaguna zen haien izaera, bioaniztasuna eta biologia. Ezaguna zen itsasoan bizi den talde horretako espezie guztiak hermafroditak zirela. Darwinek zirripedioak aztertzeko hartutako erabakian sekulako garrantzia izan zuen Beagelen egindako bidaian Txileko hegoaldeko kostaldean molusku baten oskol zulatuan aurkitutako zirripedio batek. Bildutako lanperna hori taxonomikoki sailkatu ezinik gelditu zitzaion, izendatzeke. Bitartean, «Mr. Arthrobalanus» ezizena eman zion, ematen baitzuen izaera emerik ez zuela itxuraz bi zakil zituen organismo hark [12]. Darwinen zirripedioen inguruko lan monografikoa monumentala izan zen edozein aldetatik begiratuta, eta globala. Britania Handiko Elkarte Errealeko Domina garrantzitsua eskuratzeko balio izan zion 1853. urtean. Bi azpiegitura nagusi erabili zituen bere lanean, mikroskopioa eta posta britainiarra. Bere etxean postaz, munduan sakabanaturiko museo, bilduma, naturalista, ikertzaile, oskol-biltzaileen eskuetatik jaso zituen aztertzeko eta sailkatzeko espezimenak eta aleak (nazioarteko beste egitasmo bat).

Darwinentzat sexu-desberdintzapena beti izan zen gai interesgarria, argi gelditu zenez haren azken liburuan, «Gizakiaren jatorria eta sexuari loturiko hautespena». Nahiz eta hermafroditismoa ugalketarako oso aukera arrakastatsua izan daitekeen, eboluzioan oso estrategia ezegonkorra da. Organismo bereko gonada bipartitoan energetikoki oso garestia den obozitoa ekoiztu behar da, eta aldi berean nahiko merke ateratzen den espermatozoidea. Ugalketa ulertzeko modu desberdin bi dira arrarena eta emearena, eta horrek arazo molekular, fisiologiko zein portamoldekoak sorrarazten 
ditu indibiduoan, sexu biak bereizteko joera eraginez. Horrela, espezie hermafrodita gehienak ebolutiboki oso gazteak dira. Hor hartu zuen garrantzi handia «Mr. Arthrobalanus» gure lagunak, gerora Cryptophialus minutus izena hartuko zuenak. Baita berarekin batera Darwinek aztertuko zituen Ibla, Alcippe eta Scalpellum generoko beste zenbait espeziek ere. Ibla quadrivalvis edo Scalpellum vulgare-ren kasuan, ale ar osagarriak bereiz daitezke ale hermafroditen gainean itsatsirik bizi direnak. Baina Cryptophialus minutus, Alcippe lampas eta Ibla cumingii-en kasuan bi sexu guztiz berezituak beha daitezke: eme erraldoien gainean ale ar ipotx eta parasitikoak itsatsita bizi dira. Hau da, trantsiziozko espezieen aurrean aurkitzen gara, sexuen banaketa osorako eta gonokorismorako trantsizio ebolutiboan [12]. Eboluzioaren manifestazio fenotipiko baten aurrean aurkitu zen Darwin, ziur aski bere «Origin of Species» liburuaren gauzatzean garrantzi handia izan zuena. Bere «Eureka» momentua! Esaten zuen, bai, Lamarck-ek, jadanik Aristoteles, Lineo, eta Cuvier-ek esan zuten legez, ornogabeak garrantzitsuak zirela Historia Naturala ulertzeko. Oinarrietatik hasita, konplexutasuna hobeto uler daiteke.

Argitaratu bezain pronto itsasoko ornogabeen ikerketan ari ziren ikertzaileek sutsuki lerrokatu ziren teoriaren alde. Itsas ornogabeetan zegoen nonbait harri filosofala. Lan horretan, Haeckel-en ikaslea izandako zoologo prusiar bat gailenduko zen, Anton Dohrn (1840-1909). Italiako kostaldera egindako txangoek konbentzitu zuten zientzialariek kostalde aberatsetan kokaturiko ikerketa-egoitzak behar zituztela. Azken erabakia Eboluzioaren Teoriaren aldeko frogak aurkitzeko itsas estazio bat zabaltzea izan zen Napoleseko Golkoan. Anton Dohrn-i darwinismoaren estatu-politikaria deitu izan zaio [13], baina benetan zientziaren aurrerakuntzarako ahalbideratzaile bat izan zen. Eskutitz asko trukatu zituzten berak eta Darwinek. Horietako batean, Darwinek Napoleseko itsas estazioa zabaltzearen lorpenagatik zoriontzen zion, eta diruz eta funts bibliografikoekin lagundu zuen hango liburutegi izugarria hornitzen. Anton Dohrn-en ikuspegian, itsas estazioak zabalik egon behar zuten instituzioak ziren, eta munduan barrena zientzialarientzako ostatu bilakatuko ziren itsas-behatokien sarea osatzea zen haren ametsa. Horrela defendatu zuen Britainia Handiko Zientziaren Aurrerakuntzarako Elkartearen 40. bileraren aurrean 1870n aurkeztutako txostenean. Haren ametsa, eta harekin Mesinan ikerketak buruturiko zientzialari, antropologo eta esploratzaile errusiarrarena, Nikolai Miklouho-Maclay-rena. Dohrn-en azken erabakia Napolesen bere estazioa zabaltzea izan zen, 1872. urtean, baliatuz Napoleseko itsasoaren ikerketarako baldintza metereologiko egokiak eta itsas bioaniztasun ikaragarria. Nikolaik, berriz, bazterrak nahastuko zituen Errusian, 1871. urtean Sebastopoleko Itsas Estazioa zabaldu zen arte (estazioaren azken sustatzailea Alexander Kovaleveski izango bazen ere), geroago Australiako lehen itsas estazioa (Watson's Bay, Sidney) zabalduko zuen arte, 1881.an [7]. Eta horrela, XIX. mendean dozenaka itsas estazio biologiko zabaldu ziren Europan (1. eta 2. irudiak). 
Azkenean, Anton Dohrn-ek itsas estazio bakarrean inbertituko zuen bere bizitza, baina hura munduko zientzialarientzako Meka antzeko zerbait bilakatuko zuen (1. irudia). Guztiz modu pribatuan kudeatutako instituzioan, nahiz eta finantzaketa iturriak izan Prusiako instituzioetatik ere, mahai-sistema bat ezarri zuen. Napolesen ikerketa-mahai batek lan egiteko toki bat eta honi loturiko tresneria/azpiegituren eta fauna eta flora lokalaren gaineko ezagutza eskaintzen zituen. Mahai bakoitza urte erdi edo urte osorako alokatzen zen. 1910. urtean 500 \$ ordaindu behar ziren urteko mahi batengatik, eta 50 mahai zeuden alokaturik [3]. Mahai horien bezeroak ziren Europako eta Ameriketako Unibertsitateak (Heidelberg, Wurzburg, Berlin, Cambridge, Oxford, Columbia, Pennsylvania...), ikerketa-elkarte eta erakundeak (Emakumeen Laborategiko Ikerketa Sustatzeko Napoleseko Mahaiaren Elkarte Amerikarra, Britainia Handiko Zientzia Sustapenerako elkartea, Smithsonian Institutua, Carnegie Instituzioa) eta Europako gobernuak (Prusia, Bavaria, Saxonia, Errusia, Hungaria, Errumania, Italia... Napoleseko hiria bera). Urteko alokairuak eskumena ematen zion ordaintzaileari zientzialari bat edo bi Napolesera ikerketa burutzera bidaltzeko. Dohrn-ek ez zuen ezartzen zer ikerketa egin behar zen, eta sistemak etengabeko kongresuen antzeko nazioarteko giroa sorrarazi zuen Napolesen [1, 3, 6, 13]. Mahai horietan lan egindakoek monografiak idaztera gonbidatuak izaten ziren, eta haien ikerketak Napoleseko estazioak berak argitaratutako aldizkarietan argitara zitezkeen. Zientzialari horiek bueltan beren unibertsitateko argitaletxeek argitaratutako lanak bidaltzen zituzten Napolesera, liburutegiaren edukien hazkuntza etengabean lagunduz $[1,3,6]$. Bestetik, Dohrn Ernst Abbe-ren (1840-1905) eta Carl Zeiss-en (1816-1888) lagun mina izanik, Napoles bihurtu zuen gaur egun ezagutzen ditugun mikroskopia eta prozesaketa histologikoaren sorburu. Zeiss mikroskopio berriak, disekziorako lehen mikroskopioak, lehen lente akromatikoak Napolesen erabiltzen ziren lehenik eta itsas organismoen azterketarako [6]. Eta hau horrela gertatu zen garai batean, zeinetan punta-puntako Biologiaren adarrak bilakatu baitziren Mikroskopia, Fisiologia eta Enbriologia Konparatuak, gaur egungo Biologia Molekularraren edo Genomika Konparatuaren aurretik.

Napoleseko itsas estazioan, 19 Medikuntza eta Fisiologiako edo Kimikako Nobel saridunek egin dituzte ikerketa-egonaldiak, batzuek behin baino gehiagotan (Otto Meyerhoff, Otto Warburg, Thomas Hunt Morgan edo Maurice Wilkins). Hauei gehitu behar zaie Bakearen Nobel saria (1922) irabazi zuen Fridtjof Nansen (1861-1930), arrantzuaren ikerketan, Itsasoaren Esploraziorako Nazioarteko Kontseiluaren (ICES) sorreran eta itsasoaren laginketa-metodoetan (Nansen sarea) garrantzi handia izandako zoologo, bidaiari eta abenturazale norvegiarra, bere ibilbidearen hasieran (1886) Napolesen ikerketa-egonaldi bat egin zuena [14].

Noski, bestelako itsas estazioak ez ziren modu berean kudeatzen. Anton Dohrn-en antitesia kontsidera daitekeen Henri de Lacaze-Duthiers-ek 
(1. irudia) Frantziako bi itsas estazio nagusiak zabaldu eta zuzendu zituen, Bretainiako Roscoff herrian lehena (1872) eta Mediterraneoko Banyuls sur Mer-en bigarrena (1881). Lacaze-Duthiers (1821-1901) izan zen Frantziako Itsas Biologiaren sustatzaile nagusia. Napoleseko kudeaketa elitistatzat jo zuen, eta haren esanetan itsas estazioak zientzialari guztiei zabalik egon behar zuten, dohainik [15]. Horrela zen itsaso estazio gehienetan eta ez zen inongo azpiegituren erabilerarengatik ordainketarik eskatzen. Baina horren gainetik, haren Napolesen kontrako jarrera oso oldarkorra izan zen. Anton Dohrn prusiarra zen, eta Frantzia eta Prusiaren arteko gerran (18701871) Prusia gailendu zen. Bere Sorbonako Unibertsitateko katedratik eta Pariseko Historia Naturaleko bere postu pribilegiatu eta boteretsutik, guztiz oztopatu zuen frantziar zientzialariek Napoleseko itsas estazioa bisita zezaten. Frantziak ez zuen mahairik alokairuan. Kofoidek bere liburuan 1910. urterako Napoleseko bisitari kopuruak ematen ditu. Alemaniarrak 630 izan ziren, errusiarrak 163, Britania Handikoak 153, estatubatuarrak 111, Herbeheretakoak 72 eta espainiarrak 18; frantziarrak, berriz, lau bakarrik izan ziren [3]. «Debeku» hau Lacaze-Duthiers-en heriotzaren (1901) ostetik luzatu zen 30eko hamarkadara arte. Hein handi batean, horrek justifikatzen du 2. irudian agertzen den mapan frantziar estatuan ikusten den itsas estazioen superabita $[9,15]$.

\section{ARRAINEN ESKASIA ETA ARRANTZUAREN AZTERKETA ZIENTIFIKOA}

XIX. mendean arrantzuaren gaineko eztabaida zabala zebilen pil-pilean. Leku desberdinetan azaldu ziren seinaleak zenbait arrain/moluskuren stockak arriskuan egon zitezkeelako susmopean $[1,16]$. Hau oso nabaria izan zen Britainia Handian, non iraultza industrialak aldaketa oso handiak ekarriko baitzituen: populazioaren igoera, trenbideak, eta arrastezko baporezko ontziak. Trenbideen aurretik, prozesatze-metodo tradizionaletik at gelditzen ziren arrain-espezie gutxi harrapatzen ziren. Berehala, arraina hirietako publiko handirako eskuragarri zegoen, eta arrain horien eskariari aurre egiteko teknologia garatu zen. Arraste-sare handiek ez zuten espezierik aukeratzen, tamainarik ere ez, baina metodo berriekin askoz arrain gehiago harrapatzen zen. Orduan sortu zen eztabaida $[10,16]$. Arraste-arrantzuak arrainen errute-guneak deuseztatzen ote zituen eta arrain-stockak agortu?

Egoera horretan, 1883. urtean Arrantzuaren Nazioarteko Erakusketa egin zen Londresen [16]. Huxley-ek emango zuen harrera-ekitaldiko hitzaldia, berak aztertu baitzituen britainiar gobernurako baporezko arraste-arrantzuaren gaineko arrantzale tradizionalen kezkak (1865-1866). Bakailaoaren arrautzak pelagikoak dira, hau da ur-zutabean jitoan doaz, G.O. Sars iktiologo Norvegiar ospetsuak frogatu zuen moduan, eta, froga horietan oinarrituz, Huxley-ek guztiz baztertu zuen itsas hondoetan burutu- 
riko arraste-lanek inongo eragina izan zezaketenik itsas-arrainen errute-esparruen zein ugalketaren gainean. Erakusketan emandako hitzaldian, eragin kaltegarri handia izan zuen esaldia bota zuen itsasoko arrainen estokak amaigabeak zirela defendatuz («I believe, then, that the cod fishery, the herring fishery, the pilchard fishery, the mackerel fishery, and probably all the great sea fisheries, are inexhaustible; that is to say, that nothing we do seriously affects the number of the fish. And any attempt to regulate these fisheries seems consequently, from the nature of the case, to be useless». Edwin Lankester (1847-1929) beste ideia batekoa zen, eta itsasoko bizia, bereziki arrainen bizi-zikloak eta habitatak, ikertuko zuen elkarte zientifiko baten sorreraren aldeko defentsa egin zuen, eta ikerketa hori sostengatuko zuen kostaldeko laborategi bat sortzeko beharra azpimarratu zuen.

Horrela, 1884. urtean Britainia Handiko Biologia Itsastarraren Elkartea sortu zen (Marine Biological Association of the UK) Elkarte Errealaren (Royal Society) bilera batean, Itsas Zoologia eta arrantzuaren ikerketa zientifikoa sustatzeko asmoz [10]. Huxley hautatu zuten paradoxikoki lehen lehendakari, egitasmoaren aurka azaldu zen arren, eta Lankester bilakatu zen lehen idazkaria. Plymouth aukeratu zen, hango kostaldearen bioaniztasunagatik, laborategiaren eraiketarako eta Plymoutheko Itsas Laborategiak 1888.an zabalduko zituen bere ateak. Ikerketa erakunderik ospetsuenetarikoa da, han burutu bait dituzte 12 Nobel saridunek beren ikerketak.

Hasieran arrantzuaren gaineko ikerketa, edo, Huxley-ren garaian hitz egiteko moduan, itsas ikerketa komertziala; ikerketa gehien bat aspektu biologiko (arrainen bizi-zikloak eta ugalketa, kate trofikoak, ekologia...) eta ozeanografiko (itsas korronteak, errute-esparruak) oinarrizkoetan zentratu zen. Arrantzuaren ikerketa ez zen XX. mendearen erdialdean gailenduko zen ustiaketara bideratutako diziplina ekonomikoa, matematikoa, ingeniaria eta kudeatzailea [16]. Esan dezakegu gaur egun itsas estazio biologikoek iktiologiaren ikerketa oinarrizkoan darraitela, baina gobernuen aholkularitzarako arrantzuaren ikerketa, bestelako ikerketa-entitate berezituen mendean gelditu dela.

Lehenengo arrain-markaketako esperimentuak eta iktiofaunaren ikerketa kuantitatiboak egin ziren, lehenak C.G. Johannes Petersen-en (18601929) eskutik, Danimarkako Itsas Estazioko lehen zuzendaria bera [1]. Zenbait arrain-populazioren eskasia nozitzen ari zen heinean, itsas akuikulturari erreparatu zitzaion, hasiera batean berpopulaketa-ahaleginen bitartez itsasoko arrain-stockak berreskuratzen laguntzeko asmoz. Horrela, adibidez arrain zapalen kultiborako teknikak, gaur egun erreboiloentzat erabiltzen direnak bezalakoak, Mann uharteko Port Erin Itsas Estazioan (18922005), garatu ziren. Kate trofikoaren ikerketan planktonen garrantzia nabarmendu zen, batik bat Kiel-en («Laboratorium für Intenationale Meeresforschung»), Alemanian, hasitako ikerketekin. Planktonen dinamikaren ikerketak garrantzia hartu zuen eta itsas estazio desberdinek urtero plank- 
ton-laginketak burutzen hasi ziren, gaur egun ikerketa biologikoko serie historiko luzeenetarikoak osatzen dituztenak. Adibide bat jartzearren, zooplanktoneko osagai nagusia diren kopepodoen bizi-zikloen, ugalketaren, taxonomiaren, banaketaren ikerketa gai garrantzitsua bilakatu zen.

Arrantzuaren egoeraren inguruko ardurari dagokionez, eta arazoa nazioartekoa zela ohartuta, Europako herrialde batzuek (Danimarka, Finlandia, Alemania, Herbehereak, Norvegia, Suedia, Errusia eta Britainia Handia) konbentzio baten bitartez Itsasoaren Esplorakeziorako Nazioarteko Kontseilua (ICES) ezartzea erabaki zuten, Danimarkan 1902an egindako bilkuran $[3,10,16]$. ICES gobernuen arteko itsas ikerketarako elkarte bat da, eta haren hasierako egitekoa arrantzuaren ikerketa bultzatzea izan zen. Frantzia 1920an eta Espainia 1924an bilduko ziren kontseilura. Herrialde partaideek, eta partaide izan gabe ICESekin datuak tartekatzen zituzten bestelako herrialde batzuek, azterketa hauek bermatzeko ikerketarako erakundeak irekitzea sustatu zuten beren kostaldeetan. Erakunde horiek jadanik baziren herrialdeetan diru publikoaren sarrera esanguratsua jasotzen hasi ziren lehenengoz. Ondorioz, itsas estazioek hazkundea nabaritu zuten garai hartan, bai baliabideetan eta bai pertsonal egonkorraren kontratazioan ere [10,16].

Lehen aldiz gobernuek ikerketa zientifikoaren garrantziaz ohartu ziren, «Scientia potentia est», eta arrantzuaren ikerketa (itsasoaren ikerketa komertziala) izan zen, hein handi batean, gaur egun zientzia finantziatzeko ezagutzen ditugun mekanismoak ezarri zituena $[10,16]$. Mundu osoan zehar ikerketa-zentro gehienetan egiten den ikerketaren parte nagusia diru publikoaren erabileran oinarritzen da, eta horretarako nazio desberdinek beren ikerketa-lehentasunak ezartzen dituzte. Eta, noski, haiek kudeatzeko beren ikerketa-proiektuen esleipen-sistemak argitaratzen dituzte. Itsasotik abiatu zen, halaber, nazioarteko kolaboraziorako ezinbesteko kultura zientifikoa, globalak diren arazoen konponketa bilatzeko bidean.

Atal hau bukatzeko, pasarte bat dena erraza izan ez zela erakusteko, eta zientzia aplikatuaren eta oinarrizkoaren arteko eztabaida ez dela gaurkoa erakusteko. Alexandrovsk herrixkan (gaur egun Polyarny), Artikoko lehen itsas estazioa ezarri zen San Petersburgoko Naturalisten Elkartearen eta Unibertsitatearen eskutik. 1904. urtean ireki zituen bere ateak, Barents itsasoa eta Kola penintsulako kostaldea aztertzeko, eta lekukoa hartu zion 1880. urtean zabaldu zen eta Itsas Zurian kokatuta zegoen Solovetsky-ko monasterioko itsas estazio subartikoari. German A. Kluge (1871-1956), briozooen ikertzaileentzat ezinbesteko erreferentea, izendatu zuten Alexandrovskeko Estazio Biologikoaren zuzendari 1908. urtean, eta 25 urtez jardun zuen $[1,17]$. Han jaso zuten formazioa Errusiako Artikoaren Biologiako aditu gehienak, garai zailenetan ere bai, adibidez Lehen Mundu Gerraren bitarteko okupazioan zehar eta gerra zibilak iraun bitartean. Famatuak dira Kola meridianoan zehar urteetan egindako ikerketa fisiko-kimikoak, ozeanografikoak eta biologikoak. 1925. urtean San Petersburgoko Elkarte- 
tik banatu zen, eta 1929an Estatuko Institutu Ozeanografikoaren adarra bilakatu zen, eta ikerketa-fokoa aldatu zuen Iktiologia eta arrantzuaren ikerketa ziren garrantzitsuak Estatuaren ikuspuntutik. Artikoaren baliabideen kudeaketa jarri zen jomugan. Aurrerago, 1933. urtean, «Leningradskaya Pravda» egunkariak artikulu bat argitaratu zuen, «Listorren habia» izenburua zeramana. Han, estazioko ikerketa-lanen aurka azaldu zen, eta egiten zen lana bertoko ikerltzaileen interes zientifiko baliogabeetan xahutzen zela salatu zuen, Murmansk-eko arrantzu-flotari inongo onurarik ekarri gabe. Bitartean, eta Stalin boterean zela, Baltikoa eta Itsaso Zuria lotzeko kanalaren irekieralan megalomanoak bukatu ziren urte horretan bertan. Stalinek portu segurua behar zuen bere urpekarientzat, eta Alexandrovsk-ek aukera paregabea eskaintzen zuen. Han, aukera sortu zen, eta 1933eko udan Murmansk-eko ikertzaile guztiak, G.A. Kluge barne, atxilotuak eta epaituak izan ziren. «Vermin» (basapiztiak) izendaturik «Gulag»etako lanetara kondenatu zituzten. Horrek Alexandrovsk-en amaiera ekarri zuen (ez Kluge-ren lan eskergarena) eta bertan behera utzi ziren bere instalazioak [1, 17]. Hala ere, hau ere bada itsas estazioen erresilientziaren adibide bat. Estazio biologiko baten beharra gailendu zen iparraldeko kostaldean, eta 1935. urtean estazio berria zabaldu zen Barents itsasoko kostaldean. Harrezkero kokapen- eta izen-aldaketak izan baditu ere, gaur egun lanean dirau Errusiako Zientzia Akademiaren adar gisa (http://www.mmbi.info/eng/).

\section{ITSAS ESTAZIOETAN EGIN DEN ETA EGITEN DEN EZINBESTEKO IKERKETA BIOMEDIKOA}

Geure buruari galde diezaiokegu zertarako balio duen biologo (itsas biologo) batek. Zer balio du Itsas Biologiak Nazio Batuek habian jarri behar duten 2021-2030 Garapen Jasangarrirako Itsasoaren Ikerketaren Hamarkadan? Zertarako balio dute Historia Naturalaren eta kostaldeko bioaniztasunaren inguruko ikerketek? Zertarako balio izan zuen bioaniztasunean ordena jartzeak eta espezieen arteko ahaidetasunak ezartzeak? Itsas estazio biologikoen hastapenetako lana berrikusiz zilegi izan zitezkeen galderak dira horiek. Adibidez, N. Miklouho-Maclay-k ez zuen inoiz ogibiderik izan, ez zuen inoiz ordaindutako lanpostu akademiko edo bestelakorik izan. Haren ikerketak eta espedizioak bere amarengandik eskuratutako diru-horniduraren mendean zeuden [7]. Beti bidaiatzen, eskutitzez etengabe eskatzen zion dirua, lehenengo Alemanian egindako bere ikasketak egiteko, gero bere espedizio zoologikoetarako. Ama ez zuen bereziki aberatsa, eta dirua kostata bidaltzen zion. Jakin nahi zuen diru-eskari horien zergatia [7]. Iruditeria materialista batetik, garaiko naturalista baten bizitza bohemio idealista batena zen. Biologia erromantikoa deitu zaio garaiko ikerketari. Itsas estazioen hasieran ikerketarako arrazoiak filosofikoak ziren. Galderak, filosofikoak, erantzunak filosofiko-teorikoak ziren moduan. 
Jakiteko grina zen ardatz. Jakitearren! Azken finean, Zientzietan doktore garen guztiak filosofia doktoreak gara $(\mathrm{PhD})$. Ez ahaztu, itsasoko azterketan lehen naturalisten artean arrain askoren deskribapenaren arduraduna zein arrain hermafroditen aurkitzailea Aristoteles izan zela. Itsas trikuaren aho piezari «Aristotelesen kriseilua» deritzogu, eta horrek argitzen du gure bidea eta horrek ematen digu Historia Naturalaren ikerketarako grina. Zein da «Espezieen jatorria hautespen naturalaren bidez» liburuaren balioa? Kalkulaezina modu egiaztagarri batean. Itsas estazioak urteetan itsas bioaniztasunaren behatokiak izan dira, eta hala jarraitzen dute izaten. Horrek balio handia du gaur egungo klima aldaketaren inguruko emergentziazko ikerketa-garaian. Baina izan gaitezen materialistagoak. Zenbait arrain kondriktioren arrautzak biltzen dituen eta Aristotelek deskribaturiko egitura kolagenotsuari, «Itsaslamiaren zorroa» deritzo. Zer da Itsas Biologiaren poltsak gordetzen duen baliozko edukia? Zerk azaltzen du itsas estazioen erresilientzia urte hauetan guztietan zehar, eta haien garrantzi sozio-ekonomikoa ingurumenaren ikerketa akademikotik haratago? Gaur egun, 326 eta 768 itsas estazio biologiko (itsas ikerketa instituzio) bitartean daude zabalik, estazio biologikoen datu-baseari [2] edo UNESCOri [5] erreparatzen badiegu. Non dago gure xarma?

\section{ITSAS EREDU BIOLOGIKOAK ETA ZIENTZIA ERALDATZAILEA}

Ikerketa biomedikoan, eredu biologikoen erabilera gailentzen da [18]. Badaude animalia-espezie desberdinak, beren maneiurako erraztasunagatik, ugaltzeko moduagatik, baldintza desberdinetan erantzuteko duten ahalmenagatik edota egitura konplexuak modu sinpletuan garatzeagatik prozesu molekular eta zelular desberdinen azterketa errazten dituztenak (1. taula). Horregatik, eredu biologikoak dira zenbait arazoren ikerketarako [18]. Eboluzioaren teoriak ondo jakinarazi zigun bezala, animalia guztiak ahaidetuta gaude, eta oinarri amankomunak ditugu. Gainera, Schleiden eta Schwann-en Zelulen Teoriak (1839) azaltzen duenez, biziaren unitate estrukturala zelula baldin bada eta izaki zelulanitz guztiak zelulez eraturik egonik, eredu biologiko batean aztertutako eta aurkitutako erantzun biologikoak transposagarriak izango dira animalien artean baita gizakietara ere. Iraultza kontzeptual horrek XIX. mendean egin zuen eztanda, eta itsas estazio biologikoak horren sorburuan kokatu ziren. Gogoratu horretan guztian oinarrizko Taxonomiak, Fisiologia Konparatuak edota Enbriologia Konparatua eta Esperimentalak izango zuten garrantzia. Ezinezkoa da Enbriologiako inongo azalpenik ematea knidario, molusku eta ekinodermatuekin buruturiko azterketa enbriologikoak aurkeztu gabe, edota Thomas Huxley, Hans Driesch, Jacques Loeb, Theodor Boveri edo Hans Spemann-ek eta bestelako ikertzaileek itsas eredu biologikoekin buruturiko lanak azaldu gabe [6]. 
1. taula. Ikerketa biomedikoan esanahi berezia izan duten itsas espezieak; itsas eredu biologikoak diren edo izan diren espezieak. Egindako ikerketek zenbaitetan Nobel sariak ekarri dizkiete ikertzaileei, zortzi kasu aipatzen dira hemen.

\begin{tabular}{|c|c|c|c|}
\hline $\begin{array}{l}\text { Ikerketa } \\
\text { esparrua }\end{array}$ & Taxona & Espezieen adibideak & Ikerketa-esparru zehatza \\
\hline \multirow[t]{2}{*}{ Evo-Devo } & Artopodoak & Zirripedioak & «The origin of species» \\
\hline & Kordatuak & Anfioxoa & Ornodunen eboluzioa \\
\hline \multirow[t]{2}{*}{ Genetika } & $\begin{array}{l}\text { Itsas espezie } \\
\text { desberdinak }\end{array}$ & $\begin{array}{l}\text { Bakterioak algak, ornogabe- } \\
\text { espezieak (batzuk algekin } \\
\text { sinbiosian fotosintesia buru- } \\
\text { tzeko gai: azeloak, aszidiak, } \\
\text { koralak, moluskuak...) }\end{array}$ & $\begin{array}{l}\text { Transferentzia geniko late- } \\
\text { rala }\end{array}$ \\
\hline & Ekinodermatuak & $\begin{array}{l}\text { Psammechinus microtuber- } \\
\text { culatus eta Sphaerechinus } \\
\text { granularis }\end{array}$ & Kromosomen Teoria \\
\hline \multirow{4}{*}{ Immunologia } & Moluskuak & Conus sp. & Hantura eta odol batuketa \\
\hline & Ekinodermatuak & $\begin{array}{l}\text { Itsas trikuak (Arbacia punc- } \\
\text { tulata, Stronglylocentrotrus } \\
\text { purpuratus), itsas izarrak }\end{array}$ & $\begin{array}{l}\text { Zelulen bitarteko } \\
\text { erantzun immuneak, } \\
\text { fagozitosia }\end{array}$ \\
\hline & Tunikatuak & Aszidiak & $\begin{array}{l}\text { Fagozitosia, norbera ezagu- } \\
\text { tza, HIV-ren transmisioa }\end{array}$ \\
\hline & Ornodunak & $\begin{array}{l}\text { Marrazoak eta arrain-espe- } \\
\text { zie desberdinak }\end{array}$ & $\begin{array}{l}\text { Antigorputzen eta histokon- } \\
\text { patibilitate konplexuko ge- } \\
\text { neen eboluzioa, gaixotasu- } \\
\text { nekiko erresistentzia }\end{array}$ \\
\hline \multirow{6}{*}{$\begin{array}{l}\text { Neurobiologia } \\
\text { eta } \\
\text { neurofisiologia }\end{array}$} & Azeloak & Sinsagitifera roscoffensis & Neuro-birsorkuntza \\
\hline & Moluskuak & $\begin{array}{l}\text { Txibi-espezieak (Loligo } \\
\text { forbesi), Aplysia califor- } \\
\text { nica }\end{array}$ & $\begin{array}{l}\text { Nerbio bulkada, } \\
\text { komunikazio sinapti- } \\
\text { koa eta neurotransmi- } \\
\text { soreak, sinaptogenesia, } \\
\text { memoriaren garapena }\end{array}$ \\
\hline & Artropodoak & Limulus polyphenus & Ikusmena \\
\hline & \multirow[t]{3}{*}{ Ornodunak } & Squalus acanthias & Burmuinaren funtzioa \\
\hline & & Electrophorus electricus & $\begin{array}{l}\text { Transmisio sinaptikoa } \\
\text { (ATPasa desberdinak) }\end{array}$ \\
\hline & & Torpedo $\mathrm{sp}$ & $\begin{array}{l}\text { Neuronen elektrofisiologia, } \\
\text { azetilkolinesterasaren funtzioa }\end{array}$ \\
\hline
\end{tabular}




\begin{tabular}{|c|c|c|c|}
\hline $\begin{array}{l}\text { Ikerketa } \\
\text { esparrua }\end{array}$ & Taxona & Espezieen adibideak & Ikerketa-esparru zehatza \\
\hline \multirow{5}{*}{$\begin{array}{c}\text { Zelulen } \\
\text { Biologia } \\
\text { (minbizia) eta } \\
\text { garapena }\end{array}$} & \multirow[t]{2}{*}{ Moluskuak } & Spissula solidisiima & $\begin{array}{l}\text { Zelulen zatiketa (eta } \\
\text { minbizia), ubikiutina- } \\
\text { zioa eta proteolisia } \\
\text { (eta minbizia) }\end{array}$ \\
\hline & & Loligo sp. & $\begin{array}{l}\text { Zelulen barneko } \mathrm{pH} \text {-aren } \\
\text { eta kaltzio kontzentrazioen } \\
\text { eraenketa }\end{array}$ \\
\hline & Ekinodermatuak & $\begin{array}{l}\text { Itsas trikuak (Arbacia } \\
\text { punctulata, Stronglylocen- } \\
\text { trotrus purpuratus, }\end{array}$ & $\begin{array}{l}\text { Zelulen zatiketa eta } \\
\text { ziklinak } \\
\text { Zelulen arnasketa eta } \\
\text { oxigenozko erradika- } \\
\text { len ekoizpena } \\
\text { Ernalketa } \\
\text { Garapen Biologia eta En- } \\
\text { briologia }\end{array}$ \\
\hline & $\begin{array}{l}\text { Ekinodermatuak } \\
\text { eta Tunikatuak }\end{array}$ & Itsas pepinoak, aszidiak & $\begin{array}{l}\text { Ehunen birsorkuntza, hozi } \\
\text { zelulen Biologia }\end{array}$ \\
\hline & Ornodunak & Arrain-espezieak & $\begin{array}{l}\text { Ernalketa surrogatua, game- } \\
\text { togenesia, sexu determinazio } \\
\text { eta desberdintzapena }\end{array}$ \\
\hline \multirow{3}{*}{ Fisiologia } & Artropodoak & Carcinus maenas & $\begin{array}{l}\text { Giltzurrunaren funtzioa, ioi } \\
\text { organikoen garraioa }\end{array}$ \\
\hline & \multirow[t]{2}{*}{ Ornodunak } & Opsanus tau & $\begin{array}{l}\text { Intsulinaren jariapena eta } \\
\text { diabetesa }\end{array}$ \\
\hline & & Aingirak & $\begin{array}{l}\text { Osmoeraenketa eta giltzu- } \\
\text { rrunaren funtzioa }\end{array}$ \\
\hline \multirow{3}{*}{ Zahartzea } & Knidarioak & Turritopsis dohrnii & Hilezkortasuna \\
\hline & Moluskuak & Arctica islandica & 400 urteetako biziraupena \\
\hline & Ornodunak & $\begin{array}{l}\text { Balaena mysticetus, Som- } \\
\text { niosus microcephalus }\end{array}$ & $\begin{array}{l}200 \text { eta } 400 \text { urteetako bizi- } \\
\text { raupena }\end{array}$ \\
\hline
\end{tabular}

Biologiako edo Medikuntzako edozein ikasleri galdetuta, berehala erantzungo du laborategian arazo biomedikoen azteketan Saccharomices cerevisae legamia, sagua, arratoia, ozpin-eulia edo Caenorhabditis elegans nematodoa direla ikerketa-eredu biologikoak. Har dezagun ozpin-eulia (Drosophila melanogaster), Genetikan espezie kutuna. Espeziea fokora ekarri zuen ikertzailea, eta Nobel sariaren irabazlea (1933), Thomas Hunt 
Morgan (1866-1945) izan zen. Berez itsas biologoa zen, uda bakoitzean Woods Hole-eko itsas estazioan bisitari, eta Napoles lau aldiz bisitatu zuen (1894, 1895, 1900 eta 1902). Espezie kopuru izugarriarekin lan egin zuen, itsas trikuekin batik bat. Napoleseko ikerketetan, ktenoforoen enbriologiaren azterketan aritu zen. Hari eta Theodor Boveri-ri zor diegu Herentziaren Kromosomaren Teoria, zeinetarako erabilitako eredu biologikoa ezinbestekoa itsas trikua izan baitzen [6].

Hau horrela da, itsas trikuek gametoak ekoizteko duten ahalmenagatik eta haien kanpo ernalkuntza-sistemarekin esperimentatzeko ematen dituzten erraztasunengatik (4. irudia). Adibidez, Otto H. Warburg-ek (1883-1970) bost aldiz bisitatu zuen Napoles, 1908 eta 1914 bitartean, eta ernalkuntzaren ondoren oxigeno-kontsumoan izugarrizko igoera gertatzen zela aurkitu zuen itsas trikuen enbrioietan [14]. Aurrerago, garapen goiztiarra burdinaren mendeko prozesu bat zela behatuko zuen. Horren ondorioz, haren lana zelulen arnasketan oinarritu zen, eta ondorioz, Nobel saria eskuratu zuen 1931. urtean arnasketa-entzimen inguruko azterketengatik (41 izendatze jaso zituen bere ibilbidean). Antzeko zerbait gertatuko zitzaion Otto F. Meyerhoff-i (18841951): muskuluaren glukosaren oxidazioa eta azido laktikoaren ekoizpena deskribatu zituen, eta Nobel saria irabazi zuen 1922an. Aldez aurretik itsas trikuan egingo zituen azterketa metabolikoak. Bai, Napolesen, eta bere lagunarekin Warburg-ekin elkarlanean 1910an eta 1913an [14].
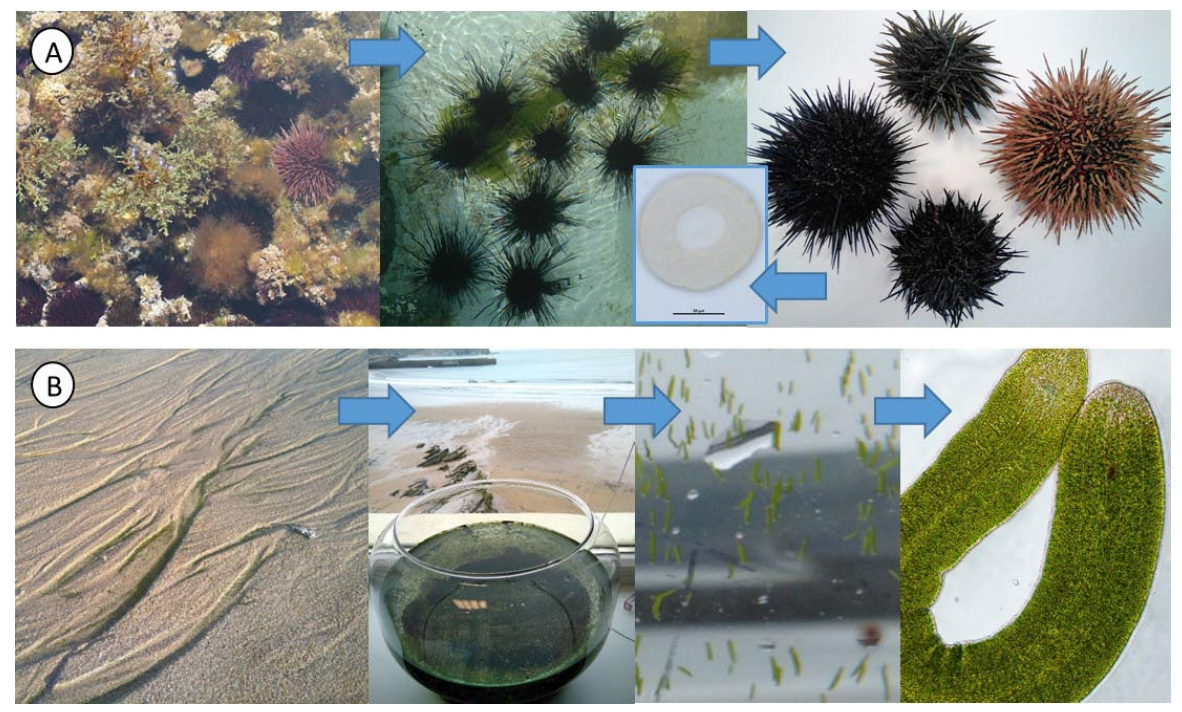

4. irudia. Itsas eredu biologikoen bi adibide; itsas trikua (A) eta Symsagittifera roscoffensis (B), zelaitik laborategira. Itsas trikuetan ikerketa askoren fokoa izan den itsas trikuaren arrautza ikus daiteke lehen kasuan, eta bigarrenean, fotosintetikoa den zizare azeloan ikusten da algetatik libre eta kolore berderik azaltzen ez duen buruaren partea. 
Baina itsas trikua bereziki ernalkuntza-prozesuaren ikerkuntzan izan da ezinbesteko eredu (1. taula). Eztabaida dago nor kontsideratu behar ote dugun ernalkuntzaren aurkitzaile. Herman Fol (1845-1892) 1880tik Villefranche sur Mer-eko Itsas Estazioko lehen zuzendaria, itsas izar batean behatu zuen espermatozoide bakarraren sarrera obozitoan. Oscar Hertwig-ek (1849-1922), aldiz, prozesu bera ikusi zuen itsas trikuan 1975ean Napolesen egindako ikerketa-egonaldi batean. Gainera, pronukleo bien fusioa deskribatu zuen enbrioiaren garapen-prozesuaren hasieran. Hari zor diogu enbrioiaren garapenerako nukleoaren ekarpenaz eta aportatzen duen materialaren garrantziaz ohartu izana. Hark behatu zuen, era berean, lehenbizikoz material genetikoaren erdibitzea meiosiaren prozesuan. Garapen Biologiako ikerketaren hastapenetan ere, August Weismann-ek (18341914) aurkitu zuen, 1881 eta 1882 bitartean, gametoak ekoiztuko dituzten ehunak (plasma germinala) gorputzaren bestelako ehunak ekoiztuko dituzten ehun aitzindarietatik banatuta garatzen direla. Non? Napolesen!

Adibide horiek itsas trikua zelulen Biologiaren, Fisiologia Zelularraren eta Biokimikaren eredu ezinbestekotzat ezartzeko balio dute. Beste adibide bat zelulen biologia molekularraren hastapenetan ziklinen aurkikuntza da. 1982an aurkitu ziren Arbacia punctulata itsas trikuaren enbrioien zatiketa zelular goiztiarra aztertzean. Tim Hunt-ek Cambridge-tik Woods Hole Itsas Laborategira egin zituen bisitetan aukera izan zuen kostaldeko faunarekin esperimentuak aurrera eramateko, eta halako batean zelulen ziklo zelularraren eraenketan ezinbestekoak diren proteina hauek aurkitu ahal izan zituen [19]. Itsas moluskuak ere izan dira ezinbesteko eredu (1. taula). Spissula solidisima muxila erraldoia izan da Joan Ruderman-en (Woods Hole-eko estazioko lehendakaria 2012 eta 2014 artean) eredu biologikoa. Huen enbrioi goiztiarrean ziklinak ere behagarri egin zituen Ruderman-ek. Avram Hershko Israeletik Woods Hole-era egindako bisitan 1991n, ubikuitina aurkituko zuen muxilaren arrautzetan, eta zelularen zikloan zeharreko ubikuitinaren bitarteko, ziklinen anderapena proteolitikoa. Horrek Kimikako Nobel saria ekarriko zion 2004an, eta, ziklinen aurkikuntzarekin batera (Nobel saria 2001), minbiziaren azterketa molekularraren iturburuan koka daitezkeen aurkikuntzak dira biak $[18,19]$.

Hala ere, moluskuen ekarpen nagusia ikerketa neurofisiologikoan zefalopodoek eta gastropodoek egin dutena izan da. Woods Hole, Plytmouth eta Napoles bitartean, Loligo generoko txibietan propultsioa eraentzen duten neuronen axon erraldoia aurkitu zen. Milimetro eta erdirainoko diametroa izan dezaketenei buruzko ikerketa esperimentala bideratzeko aproposa da. Loligo forbessi-n, eta Plymouthen errotuta, egin zituzten Alan Lloyd Hodgkin-ek (1914-1998) eta Andrew Fielding Huxley-ek (1917-2012) beren nerbio bulkadaren gaineko ikerketak (Nobel saria 1963) edota Bernard Katz-ek bereak neurotransmisioaren eta sinapsietako seinalizazioaren inguruan (Nobel saria 1970), Napolesen, kasu honetan [14, 20]. Puntako 
beste eredu biologikoa itsas erbiak izan dira, Aplysia generoko gastropodoak, hain zuzen ere. Molusku horiek babes gisa zakatzak eta sifoia ezkutatzeko erreflexuzko mugimendua dute, eta orotara 20.000 neurona handi (mm 1-eko diametrodun neuronen soma) baino ez dituzte. Ikasketa prozesu baten ondoren uzkurtze mugimendu hori gogoratzeko eta azkartzeko abilezia dute [18]. Eredu sinplea eta oso erabilgarria da sinaptogenesia, transdukzio sinaptikoa eta memoria ikertzeko garaian, eta prozesu horien gainean Arcachonen eta Californian buruturiko ikerketei esker eskuratu zuen Eric R Kandel-ek bere Medikuntzako Nobel saria 2000. urtean.

Garrantzitsuak diren zenbait prozesuren ikerketa molekular eta zelularrean erabil daitezkeen itsas organismoen adibide ugariak daude (1. taula). Har dezagun zahartzea, gaur egungo gure gizarteen erronka bat. Badago marmoka espezie bat, biologikoki hilezkorra dena, Turritopsis dohrnii. Mediterraneoan bizi diren izaki kolonial hauek gaitasuna dute beren heldutasunezko marmoka fasean, estres pean badaude edo zahartzerakoan, transdesberdintzatuz polipo faseko egoera heldugabera bueltatzeko. Horrela, beren kolonia-bizia berriz has dezakete etengabe. Gugandik gertuago, badira itsas ornodun espezieak ehundaka urte bizi daitezkeenak. Groenlandiar marrazoak du errekorra, $392 \pm 120$ urteko eme bat identifikatu delarik [21]. Baina gugandik gertuago dagoen espeziea groenlandiar balea (Balaena mysticetus) da, ugaztun bat. 2007an bale bat harrapatu zuten Alaskan, victoriar garaiko arpoi bat zuena soinean itsatsita. Haren adina? 211 urte. Zetazeo-espezie horren genoma sekuentziatua izan da, eta hasi da bere biziraupen-gaitasunaz gakoak ematen. Adibidez, DNAren konponketan garrantzitsua den gene bat, PCNA, bikoiztuta dago bere genoman [22]. Zahartze-prozesua moteltzeko gakoen azterketan lagundu dezakete espezie hauek, baina nola bermatu ehunen/organoen berritzea biziraupena luzatzen asmatzeko gai bagara? Badira itsasoan eredu biologikoak berma daketenak horren ikerketa. Itsas pepinoak estres pean edo harrapakarien presentzian beren digestio-traktua jariatzen dute babes gisa: egun batzuetan berreskuratzen dute ia osorik galdutako organoa. Beste adibide bat, azeloak, luzaro platihelminteak kontsideratuak izan diren eta hondarrean bizi diren zizaretxoak. Bada espezie bat Symsagittifera roscoffensis, Tetraselmis convolutae alga espeziearekin sinbiosian fotosintesia burutzen duena (Bailly et al., 2014). Euskal Herriko hondartzetan ohikoa da, eta itsaspean hondartzan ibiltzean zizareen pilaketak algekin nahasten ditugu (4. irudia). Zizare horiek zefalizazio-prozesu xume baten ondorioz neurona serotonergikoen, eta zelula fotohartzaile zein mekanohartzaileen metaketa dute beren aurreko ardatzean. Hau oinarrizko buru bat kontsidera daiteke. Buru serotonergiko horiek moztean zizareok hondarrean hondoratzeko mekanismoa galtzen dute. Baina neuroberriztapen-prozesu izugarri baten ondorioz, 20 egunean berriz berreskuratzen dute beren burutxoa. Hozi-zelulen ikerketan baliozko eredu biologikoa izan daiteke etorkizunean [23]. 
Azken adibidea, historian gertatutako lehenetarikoa izan daiteke. Élie Metchnikoff immunologiaren sortzaileetariko bat kontsidera daiteke. Messinan 1882. urteko udan itsas izarren larbekin lan egiteko aukera izan zuen. Zelulen mugimendua erraza da larba horietan behatzea haien izaera gardena dela eta. Larbak arrosa-arantza batekin zulatzean, behagarria zen zelula fagozitikoen mugimendua zaurien gunera. Horrek sorrarazi zituen $\mathrm{Fa}-$ gozitosiaren Teoria eta kontzeptua bera, zeinaren ordainetan 1908an Nobel saria emango baitzitzaion. Immunologiaren aita, Itsas Biologoa zen eta makina bat itsas eredu biologikorekin lan egindakoa Europako itsas estazioetara egindako bisitetan (adibidez, Napolesera edo Sebastopolera).

\section{ITSAS BALIABIDE BIOLOGIKOAK ETA «BIOTEKNOLOGIA URDINA»}

Nora zuzentzen gaitu etorkizunak? Europako Elkarteko Itsaso Arazoetarako eta Arrantzurako Zuzendaritza Orokorrak (DG-Mare) hazkunde sozioekonomiko urdinerako bere estrategian garapen bidean dauden bost jarduera identifikatu ditu. Haien artean, bik dute ikerketa biologikoa ardatz: itsas akuikultura eta itsas bioteknologia [24]. OECD-k bere 2030erako Ozeanoen Ekonomia txostenean ere bi ikerketa-esparru horiek aipatzen ditu ezinbestekotzat [25]. Zer da Bioteknologia Urdina? Egia esan, oso muga lausoak dituen esparrua da, baina oro har itsas baliabide biologikoen (IBB) gainean egindako bioteknologiaz ari gara. Beraz, itsas organismoen erabilera izango zukeen xedea gizakiarentzat onuragarriak diren produktuak edo zerbitzuak eskuratzeko [24]. IBBez ari gara, arrantzuaz eta akuikulturaz aparte. Bioteknologiak betidanik lortu ditu balio gehituko produktuak itsas organismoetatik. Feniziarrek, greziarrek edo erromatarrek arrainetatik eta arrain-soberakinetatik «garum»-a edo «liquamen»-a lortzen zituzten. Beren platerretan kondimentu gisa erabiltzen zuten arrain-salda fermentatua. Bestetik, pentsa dezagun beti boterearen, erregeen eta kardenalen ikur izan den purpura kolorean. Tindakari purpura itsas karrakeletatik lortzen zen, Muricidae familiako gastropodoetatik, eta oso garestia zen. Karrakela asko egosi behar ziren beren babes immunean erabiltzen duten bromoindigo konposatua lortzeko. Berrikiago, marmoketatik eskuratutako proteina fluoreszente berdea dugu. Osamu Shimomura-k Washington estatuko «Friday Harbor»eko itsas estazioan, 1960 eta 1970-eko hamarkadetan marmokak bildu eta gero, proteina fluoreszente hori isolatzea lortu zuen, eta egiten diren transgenesi-analisi guztietan ezinbesteko proteina «txibato» gisa erabiltzen da. Proteinatxo horrek geneen adierazpen-prozesuak behatzeko ematen duen aukeragatik, erreboluzio izugarria ekarri dizkie hozi zelulen ikerketari, klonazio-prozesuei, zelulak in vivo jarraitzea behar duten ikerketei, organoen transplanteei, neurozientziari ... Horregatik eskuratu zuen Shimomurak Kimikako Nobel saria 2008. urtean. 
2. taula. Itsas organismoak gizakientzako baliabide desberdinen iturri, batzuk historikoki ${ }^{\mathrm{H}}$ ustiatuak. Proteina fluoreszente berdearen aurkikuntzagatik Kimikako Nobel saria irabazi zuen Shimomurak.

\begin{tabular}{|c|c|c|}
\hline & Baliabidea & Iturria \\
\hline \multirow{4}{*}{ Tindakariak } & Tyroko edo Kardenalen purpura & Muricidae gastropodoak ${ }^{\mathrm{H}}$ \\
\hline & Tinta beltza & Zefalopodoak \\
\hline & Karotenoideak & Itsas bakterio, onddo eta algak \\
\hline & $\begin{array}{l}\text { Tindakari fluoreszenteak (proteina } \\
\text { fluoreszente berdea, fikoeritrina, } \\
\text { fikozianina...) }\end{array}$ & $\begin{array}{l}\text { Marmokak, zianobakterioak, } \\
\text { mikroalgak }\end{array}$ \\
\hline \multirow{3}{*}{$\begin{array}{l}\text { Nutrazeutikoak } \\
\text { eta } \\
\text { probiotikoak }\end{array}$} & Bitaminak & Bale eta arrainen gibelak \\
\hline & Omega-3 gantz azidoak & Algak, itsaskiak \\
\hline & Elikagaientzako gehigarriak & Algak, zianobakterioak \\
\hline \multirow{7}{*}{ Kosmetikoak } & $\begin{array}{l}\text { Krema hidratatzaileak: kolage- } \\
\text { noak }\end{array}$ & $\begin{array}{l}\text { Arrain eta marmoka espezie des- } \\
\text { berdinak }\end{array}$ \\
\hline & $\begin{array}{l}\text { Krema hidratatzaileak: polisakari- } \\
\text { doak eta gantz azidoak (sophoroli- } \\
\text { pidoak, rhamnolipidoak eta } \\
\text { mannosilerithritol), omega-3 gantz } \\
\text { azidoak }\end{array}$ & Makro eta mikroalgak \\
\hline & $\begin{array}{l}\text { Konposatu fungizidak eta antihe- } \\
\text { morragikoak (kitosanoa) }\end{array}$ & Krustazeoak eta itsas onddoak \\
\hline & $\begin{array}{l}\text { Konposatu antioxidatzaileak (ka- } \\
\text { rotenoideak, konposatu fenoli- } \\
\text { koak...) }\end{array}$ & $\begin{array}{l}\text { Makro eta mikroalgak, itsas halo- } \\
\text { fitoak }\end{array}$ \\
\hline & $\begin{array}{l}\text { Konposatu foto babesleak eta } \\
\text { UVA zurgatzaileak }\end{array}$ & $\begin{array}{l}\text { Zianobakterioak, algak, itsas pe- } \\
\text { pinoak }\end{array}$ \\
\hline & $\begin{array}{l}\text { Larruazalaren zuritzaileak eta tiro- } \\
\text { sinasa entzimaren inhibitzaileak }\end{array}$ & Itsas bakterioak eta algak \\
\hline & $\begin{array}{l}\text { Eszipienteak eta kosmetikoetarako } \\
\text { gehigarriak (antimikrobialak) }\end{array}$ & Algak, bakterioak, krustazeoak \\
\hline \multirow{5}{*}{$\begin{array}{l}\text { Industriarako } \\
\text { gaiak }\end{array}$} & Substratuak jardinetan & Diatomeoak \\
\hline & Zelulosa & Aszidiak \\
\hline & Olioa eta olio esentzialak & Baleak $^{\mathrm{H}}$, arrainak \\
\hline & Ongarriak & Baleak $^{\mathrm{H}}$ eta itsaskien hondakinak \\
\hline & Entzimak & Algak, bakterioak \\
\hline
\end{tabular}




\begin{tabular}{l|l|l}
\hline & \multicolumn{1}{|c|}{ Baliabidea } & \multicolumn{1}{c}{ Iturria } \\
\hline \multirow{4}{*}{ Farmakoak } & Analgesikoak & Prialt (Conus sp.) \\
\cline { 2 - 3 } & Minbiziaren aurkako farmakoak & Yondelis (Ecteinascidia turbinata) \\
\cline { 2 - 3 } & Mitosiaren inhibitzaileak & Dolastatinak (Zianobakterioak) \\
\cline { 2 - 3 } & $\begin{array}{l}\text { Antibiralak eta immunoezabatzai- } \\
\text { leak }\end{array}$ & Didemnin B (Tunikatuak) \\
\cline { 2 - 3 } & $\begin{array}{l}\text { Angiogenesia, zelulen desberdin- } \\
\text { tzapena eta apoptosia }\end{array}$ & Bryostatin (Briozooak) \\
\hline
\end{tabular}

XXI. mendean, eta batik bat, sekuentziazio masibo paraleloko teknikek ahalbidetutako genomen azterketarako, eta funtzio biologikoen screening multipleak egiteko aukerekin itsasoaren bioprospekzioa bilakatu da ohikoa [24]. IBBetan elikadurarako produktuak eta nutrazeutikoak edo probiotikoak bilatzen dira, eta bolo-bolo dabiltza omega-3 gantz azidoen onurak (2. taula). Hasiak gara algetan gure begiak jartzen gure elikaduran sartzeko. Baina screening-etan mota guztietako berezitasunak bilatzen dira izaki horien molekula eta metabolitoetan (2. taula). Berezitasun immunoezabatzaileak, immunosustatzaileak, antibiotikoak edo fungizidak ote dituzten ikertzen dugu. Aztertzen da ea antiproliferatzaileak izan ote daitezkeen minbiziaren aurkako farmakoen garapenean. Konposatu hidratatzaileak, antioxidatzaileak edo foto-babesleak bilatzen ditugu kosmetikoetan erabiltzeko [26]. Aukerak izugarriak dira, bizia itsasoan orain dela 4 bilioi urte sortu zelako, eta, animaliei bakarrik erreparatzen badiegu, existitzen diren 36 filumetatik 34 itsasoan ordezkatuak daudelako, lur lehorrean 17 bakarrik dauden bitartean. Eboluzioak milioika urte daramatza jolasean itsasoan eta mota guztietako molekulak sortzen.

Izugarrizko potentziala, bai, baina bioteknologiako industriak ez dio behar duen beste erreparatzen itsasoari, parte batean itsasoaren biotaren azterketak bere zailtasunak dituelako [24]. Hor egongo da, hein handi batean, itsas estazioek garatu beharreko esparru berria eta asmo horrekin Europar Elkarteak IBBen Ikerketarako Zentroa (EMBRC, ingelesezko siglak sortu du nazioarteko ikerketa azpiegitura gisa (www.embrc.eu). Bederatzi herrialdetan barreiaturik den azpiegitura da, Belgika, Britainia Handia, Espainia, Frantzia, Grezia, Israel, Italia, Norvegia eta Portugaleko 29 itsas estazio eta ikerketa-zentroz osatua. Plentziako Itsas Estazioa bertan da, Vigoko Unibertsitateko Itsas Estazioarekin batera, espainiar Estatua ordezkatuz. Gure xedea IBBak eskuragarri egitea da, eta, haien erabilera bioteknologikorako zerbitzuak eskainiz, Europan garatu beharreko Bioteknologia Urdina katalizatzea. Urte askotarako! 


\section{ESKER ONAK}

Lan hau Assemble+H2020 europar proiektuaren (INFRAIA-01-20162017) eta Eusko Jaurlaritzako talde kontsolidatuaren (IT1302-19) baitan egin da.

\section{BIBLIOGRAFIA}

[1] EGERTON, F.N., 2014. «History of Ecological Sciences, Part 51: Formalizing Marine Ecology, 1870s to 1920s». Bull. Ecol. Soc. Amer. 95, 347-430.

[2] TYDECKS, L., BREMERICH, V., JENTSCHKE, I., LIKENS, G.E., TOCKNER, K., 2016. «Biological field stations: a global infrastructure for research, education, and public engagement». BioScience, 66, 164-171.

[3] KOFOID, C.A., 1910. «The biological stations of Europe». United States Bureau of Education bulletin. no. 4.

[4] YONGE, C.M., 1956. «Development of marine biological laboratories». Sci. Prog. 44, 1-15.

[5] UNESCO 2017. «Global Ocean Science Report. The current status of Ocean Science around the World» (Valdes, L. et al., edk.), UNESCO Publishing, Paris.

[6] FANTINI, B. 2000. «The «Stazione Zoologica Anton Dohrn» and the history of embryology». Int. J. Dev. Biol. 44: 523-535.

[7] WEBSTER, E.M., 1984. «The moon man. A biography of Nikolai Miklouho-Maclay». The University of California Press, orr. 421.

[8] BENSON, K.R., 1988. «Why American marine stations?: the teaching argument». Amer. Zool. 28, 7-14.

[9] PAUL, H.W., 1985. «From knowledge to power. The rise of the science empire in France, 1860-1939». Cambridge, Cambridge University Press, IX-415 orr.

[10] VAN BENNEKOM, A.J., 2013. «Political factors in the establishment of biological stations before 1900. Groeben, C. (ed.) «Places, People, Tools: Oceanography in the Mediterranean and Beyond. Proceedings of the Eighth International Congress for the History of Oceanography». Pubblicazioni della Stazione Zoologica Anton Dohrn, IV: orr. 125-139.

[11] RAMON Y CAJAL, S., 1917. «Contribución al conocimiento de la retina y centros ópticos de los cefalópodos». Trabajos del Laboratorio de Investigaciones Biológicas. XV, Madrid.

[12] BUCHANAN, R.D., 2017. «Darwin's "Mr. Arthrobalanus": sexual differentiation, evolutionary destiny and the expert eye of the beholder». J. Hist. Biol. 50, 315-355.

[13] GROEBEN, C., 1985. «Anton Dohrn-the statesman of Darwinism». Biol. Bull. 168, 4-25.

[14] GROEBEN, C., De Sio, F., 2006. «Nobel laureates at the Stazione Zoologica Anton Dohrn: phenomenology and paths to discovery in neuroscience». J. Hist. Neurosci. 15, 376-395. 
[15] DAYRAT, B., 2016. «Henri de Lacaze-Duthiers and the creation of the Laboratoire de zoologie expérimentale. Roscoff, France». Revue s'histoire des sceinces, 69, 335-368.

[16] HUBBARD, J., 2014. «In the wake of politics: the political and economic construction of fisheries biology, 1860-1870». Isis, 105, 364-378.

[17] GINETSINSKAYA, T.A., 1995. «The creation of the first marine biological stations in North Russia». Helgoländer Meeresuntersuchungen, 49, 459-463.

[18] OCEAN STUDIES SCIENCE BOARD 1999. «From Monsoons to microbes:understanding the ocean's role in human health». Washington, DC: National Academy Press. 132 orri.

[19] HUNT, T., 2004. «The discovery of cylcin». Cell, S116, S63-S64.

[20] SCHWIENING, C.J., 2012. A brief historical perspective: Hodgkin and Huxley». J. Physiol. 590, 2571-2575.

[21] NIELSEN, J., HEDEHOLM, R.B., HEINEMEIER, J., BUSHNELL, P.G., CHRISTIANSEN, J.S., OLSEN, J., RAMSEY, C.B., BRILL, R.W., SIMON, M., STEFFENSEN, K.F., STEFFENSEN, J.F., 2016. «Eye lens radiocarbon reveals centuries of longevity in the Greenland shark (Somniosus microcephalus)». Science. 353, 702-704.

[22] KEANE, M., SEMEIKS, J., WEBB, A.E., LI, Y.I., QUESADA, V., CRAIG, T., MADSEN, L.B., VAN DAM, S., BRAWAND, D., MARQUES, P.I., MICHALAK, P., KANG, L., BHAK, J., YIM, H.S., GRISHIN, N.V., NIELSEN, N.H., HEIDE-JØRGENSEN, M.P., OZIOLOR, E.M., MATSON, C.W., CHURCH, G.M., STUART, G.W., PATTON, J.C., GEORGE, J.C., SUYDAM, R., LARSEN, K., LÓPEZ-OTÍN, C., O’CONNELL, M.J., BICKHAM, J.W., THOMSEN, B., DE MAGALHÃES, J.P., 2015. «Insights into the evolution of longevity from the bowhead whale genome». Cell Rep. 10, 112-122.

[23] BAILLY X, LAGUERRE L, CORREC G, DUPONT S, KURTH T, PFANNKUCHEN A, ENTZEROTH R, PROBERT I, VINOGRADOV S, LECHAUVE C, GARET-DELMAS MJ, REICHERT H, HARTENSTEIN V. (2014). «The chimerical and multifaceted marine acoel Symsagittifera roscoffensis: from photosymbiosis to brain regeneration». Front Microbiol. 5, 498.

[24] HURST, D., BØRRESEN, T., ALMESJÖ, L., DE RAEDEMAECKER, F., BERGSETH, S., (2016). «Marine biotechnology strategic research and innovation roadmap: Insights to the future direction of European marine biotechnology». Marine Biotechnology ERA-NET: Oostende. pp. 64.

[25] OECD 2016. «The Ocean Economy in 2030». OECD Publishing, Paris. http://dx.doi.org/10.1787/9789264251724-en

[26] GUILlERME, J.B., COUTEAU, C., COIFFARD, L. 2017. «Applications for marine resources in cosmetics». Cosmetics $\mathbf{4}, 35$. 